\title{
PERANCANGAN PEMBANGKIT LISTRIK TENAGA SURYA (PLTS) PEMBASMI SERANGGA PADA TANAMAN BAWANG MERAH DI KABUPATEN BREBES
}

\author{
Sudarmono ${ }^{1)}$, Joko Waluyo ${ }^{2)}$, Wahyu Wilopo ${ }^{3)}$ \\ Magister Teknik Sistem UGM ${ }^{1,2,3)}$ \\ Kompleks Bulaksumur, JL.Sosio Humaniora, Karang Malang, Catur Tunggal, Depok, \\ Sleman, Yogyakarta, 55281 \\ Email: $\underline{\text { sudarmono92@mail.ugm.ac.id }}{ }^{1)}$, jokowaluyo@ugm.ac.id ${ }^{2)}$ wwilopo@ gmail.com $^{3)}$
}

\begin{abstract}
ABSTRAK
Indonesia terletak pada iklim khatulistiwa, sehingga Indonesia mempunyai sumber energi surya yang berlimpah dengan intensitas radiasi matahari rata-rata sekitar 4,8 kWh/m2 perhari diseluruh wilayah. Sel surya semakin populer bagi masyarakat karena sumber energi yang tidak terbatas dan ramah lingkungan. Melihat jumlah fosil saat ini digunakan sebagai pembangkit energi listrik terus berkurang, jika dibiarkan terus terjadi, maka sumber energi ini akan habis. oleh karena itu para ilmuwan berlomba-lomba mencari cara untuk meningkatkan efisiensi energi terbarukan sebagai sumber pembangkit energi listrik salah satunya adalah panel surya. Kabupaten Brebes terletak antara 6044'-7021' Lintang Selatan dan 108041'-109011' Bujur Timur. Budidaya tanaman bawang merah merupakan Produk unggulannya dengan jumlah produksi mencapai 272.598,8 (Ton) pada tahun 2017. Para petani dalam membasmi hama serangga yang tidak merusak lingkungan adalah menggunakan lampu pada malam hari sebagai media perangkap serangga atau wereng. Alternatif sumber energi listrik untuk menyalakan lampu dari tenaga matahari dengan memanfaatkan panel surya akan menyimpan energi listrik pada aki disiang hari dan pada malam harinya bisa digunakan untuk menyalakan lampu. Penelitian ini bertujuan untuk mengetahui kelayakan PLTS di pertani bawang merah, metode ini difokuskan pada pendekatan pertama estimasi kebutuhan listrik yaitu melalui data sekunder, lampu led menyala selama 12 jam beban lampu 1 watt dengan modul PV 3 watt, 6 Volt menggunkan baterai lithium 3,7 volt dengan kapasita 3,4 Ah lama pengisian 3,46 jam dan lama penyinaran matahri pada PV 4 jam. Dari hasil tersebut maka PLTS dikatakan layak untuk menjadi energi alternatif.
\end{abstract}

Kata kunci: baterai lithium, lampu led dc, panel surya, pembasmi serangga.

\section{ABSTRACT}

Indonesia is located on the equator, so Indonesia has a large source of solar energy with an average solar radiation intensity of about $4.8 \mathrm{kWh} / \mathrm{m} 2$ per day throughout the region. Solar cells are increasingly popular with the community because of their unlimited energy sources and environmentally friendly. See the current number of fossils used as power plants continue to decrease, if left continuously, then this energy source will be depleted. Therefore scientists are vying for ways to increase renewable energy efficiency as a source of electrical energy generation One of them is solar panels. Brebes County is located between 6044 '-7021 ' south latitude and 108041 '-109011 'east longitude. The cultivation of red onion plants is an flagship product with a production of 272,598.8 (Ton) in the year 2017. Farmers in eradicating insect pests that do not damage the environment is to use lamps at night as an insect trap media or planthopper. Alternative sources of electrical energy to light the lamp from solar energy by utilizing the solar panels will store the electrical energy on the battery of the day and at night can be used to light the lights. The research aims to determine the feasibility of a PLTS in the red onion farm, this method is focused on the first approach of estimation of electrical needs through secondary data, LED lights on for 12 hours of 1 watt lamp load with 3 watt PV module, 6 Volt Use 3.7 volt lithium battery with 3.4 Ah old capacity charging 3.46 hours and long the illumination of the Matahri on a 4hour PV. From these results, the PLTS are said to be worthy of alternative energy.

Key words: Insect repellent, lithium battery, DC LED light, solar panels 


\section{PENDAHULUAN}

Reaksi fusi nuklir yang terjadi di dalam inti matahari dapat menghasilkan radiasi yang berbentuk energi surya. Di seluruh wilayah indonesia memiliki sumber energi surya yang berlimpah dengan rata rata intensitasnya sekitar $4,8 \mathrm{kWh} / \mathrm{m} 2$ perhari [1]. Kondisi di atas menunjukkan bahwa wilayah indonesia mempunyai potensi yang besar dalam pemanfaatan energi cahaya matahari sebagai energi alternatif pembangkit energi listrik. Salah satu sumber energi alternatif tersebut adalah sel surya, sumber energi ini menjadi semakin dikenal oleh masyarakat umum karena jumlahnya yang tidak terbatas dan ramah lingkungan. Dengan semakin berkurangnya jumlah energi fosil yang ada saat ini, maka para ilmwan kemudian berlomba-lomba untuk menemukan cara meningkatkan efisiensi energi terbarukan sebagai sumber pembangkit energi listrik. Wilayah Kabupaten Brebes berada diantara 6044'-7021' Lintang Selatan dan 108041'-109011' Bujur Timur. Tanaman yang menjadi produk unggulan di wilayah ini adalah budidaya tanaman bawang merah dengan hasil produksinya yang mencapai jumlah 272.598,8 (Ton) di tahun 2017.[2]. Salah satu masalah yang dapat mengurangi produksi tanaman bawang merah di Kabupaten Brebes adalah serangan dari hama serangga atau wereng. Serangan ini sekarang terjadi semakin meningkat di beberapa kecamatan di Kabupaten Brebes. Cara petani dalam membasmi serangan hama serangga yang tidak merusak lingkungan adalah dengan menggunakan lampu pada malam hari, cara ini digunakan sebagai media perangkap serangga atau wereng. Salah satu energi alternatif yang digunakan untuk menyalakan lampu yaitu dengan memanfaatkan tenaga matahari dengan panel surya yang dijadikan sumber penyimpanan energi listrik pada aki disiang hari dan pada malam harinya dapat digunakan untuk menyalakan lampu. Di wilayah ini Energi listrik dapat diperoleh dari PLN setempat, tetapi lokasi dari ladang petani yang jaraknya jauh dari pemukiman warga, maka sulit untuk dijangkau, selain itu pula alasan lainnya adalah sulitnya mendapatkan perizinan dari pemilik ladang sekitar dengan alasan membahayakan warga sekitar. Alternatif lain yang biasa digunakan oleh para petani bawang merah adalah energi listrik dari tenaga matahari yakni dengan memanfaatkan panel surya. Dari hasil kajian sebelumnya yang telah di lakukan oleh Muhammad Suyanto, dkk tentang peralatan perangkap serangga (PPS). Dapat diketahui bahwa dalam proses pengisian baterai dari panel surya yang diisi secara maksimal, dari pukul 09.00 WIB - pukul 16.00 WIB menghasilkan rata - rata tegangan dan arus pada setiap jamnya sebesar 14,70 volt dan 0,60 ampere. Sedangkan daya untuk alat dapat bekerja dalam satu malam (12 jam) yang diperlukan untuk menyuplai beban lampu LED dan kawat elektrik adalah sebesar 89,58 watt [3]. Panel surya akan menyimpan energi listrik pada aki di siang hari dan pada malam harinya dapat digunakan untuk menyalakan lampu. Dengan demikian para petani tidak mengeluarkan biaya tambahan, penelitian ini akan dilakukan Kecamatan Larangan Kabupaten Brebes.

\section{TINJAUAN PUSTAKA}

\subsection{Pembangkit Listrik Tenaga Surya (PLTS)}

Bentuk pemanfaatan energi matahari secara langsung dapat berupa energi panas (energi termal) dan energi listrik (fotovoltaik). Untuk mengubah energi matahari menjadi enegi listrik dapat menggunakan sel surya. PLTS digunakan untuk memenuhi pelayanan listrik di negara 
berkembang yang jaringan listriknya masih belum menjangkau daerah pedesaan, ataupun daerah yang masih lama untuk mendapatkan layanan jaringan listrik. Selain itu biaya PLTS juga terjangkau jika dibandingkan harus menggunakan diesel yang bahan bakarnya terlalu mahal atau pasokannya sering terganggu. PLTS juga dimanfaatkan untuk berbagai keperluan yaitu keperluan rumah tangga, sekolah, UMKM, kesehatan dan lainnya [4].

\subsection{Prinsip Kerja Sistem PLTS}

Dalam membangun Pembangkit listrik tenaga surya dapat menggunakan tiga tipe skema jaringan antara lain: on-grid, off-grid (stand alone), dan hybrid.

- Pertama yaitu Skema jaringan on-grid adalah skema jaringan dimana jaringan listrik lokalnya (jaringan listrik PLN) dihubungkan dengan pembangkit listrik tenaga surya. Pada Skema jaringan on-grid inverter yang berfungsi untuk mengubah listrik DC yang dihasilkan sel surya menjadi listrik AC yang sesuai dengan jaringan lokal dan di dukung dengan instrumen lain untuk menstabilkan koneksi jaringan.

- Kedua yaitu Skema dalam jaringan off-grid yang tidak menghubungkan dengan jaringan lokal, pada skema jaringan ini energi listrik disimpan dalam baterai yang dapat digunakan ketika produksi listrik tidak mencukupi atau bisa juga digunakan pada saat malam hari. Seperti halnya pada jaringan on-grid, aliran listrik DC pada jaringan inipun bisa diubah menjadi listrik AC agar dapat dimanfaatkan. Skema off-grid ini sesuai untuk daerah yang jauh dari jaringan listrik.

- Ketiga yaitu skema jaringan hybrid di mana pada skema jaringan ini pembangkit listrik tenaga surya digabungkan dengan teknologi pembangkit listrik yang lain [5].

\subsection{Penentuan Potensi}

Pada prinsipnya, seluruh wilayah di Indonesia memiliki potensi untuk dibangun PLTS. Namun, untuk memastikan masa operasi PLTS tersebut berkelanjutan dalam jangka panjang, sebaiknya penetapan pembangunan PLTS juga mempertimbangkan antara lain:

- Tersedianya lahan sebagai tempat pembangunan PLTS, lahan dapat dibuat diatas tanah maupun di atas atap (rooftop) dengan luasan yang memadai.

- Teknologi jika menggunakan teknologi PLTS, diusahakan menggunakan teknologi baterai dengan umur pakai yang lebih panjang sehingga tingkat keberlanjutan pembangkit lebih baik.

- Iuran listrik kemampuan dan kemauan msyarakat untuk membayar listrik dari pembangkit PLTS sangat penting untuk keberlangsungan akses listrik mengingat biaya penggantian baterai dan inverter yang cukup signifikan.

\subsection{Estimasi Awal Kebutuhan Listrik}

Hal selanjutnya yang perlu dilakukan adalah perhitungan atau memperkirakan kebutuhan listrik yang digunakan di lokasi tersebut. Hasil perkiraan kebutuhan listrik akan menjadi penentu besarnya kapasitas PLTS yang perlu disedikan di lokasi tersebut. Perkiraan dilakukan dengan menggunakan dua pendekatan, yaitu penentuan awal pra survei dengan menggunakan data sekunder, kemudian dilanjutkan dengan melakukan survei di lapangan. Pada tahapan ini, 
pembahasan akan difokuskan pada pendekatan pertama perkiraan kebutuhan listrik pada lokasi tersebut, yaitu dengan melalui data sekunder. Hal ini perlu dilakukan terutama apabila penyusunan studi kelayakan PLTS dilakukan oleh konsultan. Kemudian hasil perhitungan perkiraan kebutuhan listrik ini dapat dijadikan dasar dalam penyusunan Term Of Refrence (TOR) pekerjaan konsultan.

\subsection{Serangga}

Salah satu sifat serangga yaitu memiliki ketertarikan pada cahaya, dari hal itu maka telah ada beberapa peneliti yang melakukan penelitian terkait hal tersebut, misalnya penelitian tentang menggunakan lampu petromak untuk menangkap serangga (laron), penelitian tentang menangkap lalat buah dengan warna kuning, penelitian tentang menangkap lalat dengan waranwarni yang mencolok dan penelitian tentang menangkap nyamuk dengan lampu ultra violet. Cahaya memiliki daya tarik dan mampu mempengaruhi perilaku serangga dengan intensitas tertentu akan diperoleh efisiensi sumber energi serta daya pikat untuk mengumpulkan serangga. Kemampuan tersebut bisa menjadi alat pengendali populasi serangga yang tidak menguntungkan dengan pendekatan ramah lingkungan, disamping itu juga memperoleh serangga dapat dijadikan sumber pakan ternak. Merancang alat yang efektif dan efisien agar cahaya mampu digunakan secara praktis di lahan-lahan pertanian [6].

\section{METODE PENELITIAN}

Untuk membantu para petani bawang merah dalam mengatasi serangan hama serangga (wereng) maka peneliti mengusulkan solusi yaitu dengan dibuatnya desain alat perangkap hama serangga menggunakan metode lampu led. Pada metode ini untuk memperoleh sumber listrik maka peneliti menggunakan panel surya yang disimpan di dalam baterai, selanjutnya adalah menyiapkan air sabun dibawah lampu led agar hama serangga dan wereng terperangkap oleh air sabun tersebut. Pada tahapan penyelesaian penelitian ini dilakukan dengan menggunakan studi literatur pencarian informasi baik dari buku, jurnal, bahan dari internet maupun sumbersumber yang berkaitan dengan penelitian ini, di antaranya: Pembangkit Listrik Tenaga Surya (PLTS), Konverter AC-DC, Sistem jaringan pembangkit, Sistem energi terbarukan, Prototype pembangkit, Perancangan sistem pembangkit.

\section{HASIL DAN PEMBAHASAN}

Penelitian ini bertujuan untuk mengetahui kelayakan PLTS di pertani bawang merah, metode ini difokuskan pada pendekatan pertama estimasi kebutuhan listrik yaitu melalui data sekunder, lampu led menyala selama 12 jam beban lampu 1 watt dengan modul PV 3 watt, 6 Volt menggunkan baterai lithium 3,7 volt dengan kapasita 3,4 Ah lama pengisian 3,46 jam dan lama penyinaran matahri pada PV 4 jam. Dari hasil tersebut maka PLTS dikatakan layak untuk menjadi energi alternatif.

Jika pada penelitian sebelumnya menggunakan cahaya lampu UV, kebaruan penelitian ini adalah pada desain lampu led, hal ini melihat dari kebutuhan data sekunder yang menjelaskan bahwa lampu led banyak digunakan oleh para petani bawang merah. Gambar alat yang dirancang adalah sebagai berikut: 




Gambar 1. Desain Alat

\section{KESIMPULAN}

Telah didesain alat pembasmi hama serangga dan wereng dengan lampu led yang sumber listriknya dari panel surya. Berdasarkan studi literatur yang telah dilakukan, alat dapat berfungsi dengan pengisian baterai berlangsung 3,46 jam dan menggunakan baterai lithium rangkaian paralel 3,7 Volt, $3400 \mathrm{mAh}$ dan lama penyinaran matahari pada panel surya 4 jam mampu menyalakan lampu led dengan beban 1 watt selama 12 jam, maka PLTS dikatakan layak menjadi energi alternatif bagai para petani bawang merah di Kabupaten Brebes.

\section{UCAPAN TERIMAKASIH}

Terimaksih kepada para petani bawang merah di Kecamatan Larangan Kabupaten Brebes atas bantuan hibah dana penelitian yang telah diberikan dalam proses penelitian ini.

\section{DAFTAR PUSTAKA}

Syahbanna Anhar Aulia,Ira Devi Sara dan Ramdhan Halid Siregar. "Desain Prototype Sel Surya Terkonsentrasi Menggunakan Lensa Fresnel,” 2017, vol. 2 No.3, hlm. 1-7.

Badan Pusat Statistik. 2018. KABUPATEN BREBES DALAM ANGKA 2018. BPS Kabupaten Brebes.

Suyanto Muhammad, Subandi dan Encep Imam Cademas. "Sistem Peralatan Perangkap Serangga Tanaman Padi Dengan Panel Surya Sebagai Catu Daya," hlm. 1-6.

Budiarto Rachmawan, Derajad S. Widhyharto, Agus Prasetya, Ahmad R.Wardhana dan Jagad Jati Hidayat. "Energi Surya Untuk KomunitasMeningkatkan Produktivitas Masyarakat Pedesaan Melalui Energi Terbarukan". LAKPESDAM-PBNU, 2017.

Kencana Bayuaji, Budi Prasetyo, Hanny Berchmans, Imas Agustina, Puteri Myrasandri, Raymond Bona, Richard Randy Panjaitan dan Winne. "Panduan Studi Kelayakan Pembangkit Listrik Tenaga Surya (PLTS) Terpusat - Kementerian ESDM Republik Indonesia." Nov-2018.

Subandi. "PEMBASMI HAMA SERANGGA MENGGUNAKAN CAHAYA LAMPU BERTENAGA SOLAR CELL," Agustus 2016, vol. 9 NO.1, hlm. 1-7. 